\title{
On the Responsible Investment Disclosure Practices of the World's Largest Pension Funds
}

\author{
by Robert J. Bianchi*, Michael E. Drew and Adam N. Walk \\ Griffith Business School, Griffith University, Queensland, Australia
}

\begin{abstract}
:
Purpose - This study measures the level of responsible investment (RI) disclosure of the world's largest pension funds.

Design/methodology/approach - The public disclosure of environmental, social and governance (ESG) factors by the world's largest pension funds reflect their genuine commitment to this new investment paradigm. The UNPRI criterion is employed to measure the level of public disclosure. One hour was allocated to every asset owner's web site to search and collect public information.

Findings - Overall, the level of public disclosure of RI activities is not prolific. The study is negatively influenced by North American pension funds who dominate this sample. Public disclosure practices are positive for European funds. The size of funds under management positively influences the public disclosure and reflects their leadership role in the industry.

Research limitations/implications - Limitations include: the largest pension funds are dominated by North American funds and reflect the impact of fund size. The results are from the largest pension funds and may not be representative of the entire industry; the positive findings from European funds reflect a material subset of the global asset owners; and, we do not engage directly with the funds in question. Measurements are sourced from public disclosure.

Originality/value - The lack of public disclosure of RI by North American funds suggests that these institutions do not believe that it is important to investors. It suggests that these asset owners haven't yet been exposed to the same influences as European funds. Given that North American funds together own substantial interests in listed corporations, they are much more important to influence than corporations.
\end{abstract}

Keywords - Responsible Investing, Sustainable Finance, ESG, SRI, Ethical Investing

JEL Classification - G11, G23

* Corresponding author. Email: r.bianchi@griffith.edu.au We thank the two anonymous reviewers for their comments and suggestions. We are also grateful for the comments and feedback from the 2009 symposium participants of the Asia Pacific Centre for Sustainable Enterprise, Griffith Business School. 


\section{Introduction}

In recent years, the global finance industry has witnessed the rise of environmental, social and governance (ESG) factors as potentially important criteria in the investment decision-making process. The emergence of organisations and initiatives including the United Nations Principles for Responsible Investment (UNPRI), the Carbon Disclosure Project, the Investor Group on Climate Change, Enhanced Analytics Initiative (EAI), International Corporate Governance Network (ICGN), Investor Network on Climate Risk (INCR), Coalition for Environmentally Responsible Economies (CERES), Council of Institutional Investors (CII), Institutional Investors Group on Climate change (IIGCC) and many others, have provided impetus to ESG factors as inputs when making responsible investment decisions.

The ideal of responsible investing (RI) has been largely defined within the realms of socially responsible investing (SRI), ethical investments and corporate social performance. The recent emergence of ESG factors attempts to more clearly define the various aspects of responsible investment decision making. The question remains whether the custodians of the largest pools of long-term savings are genuinely committed to the new ESG investment paradigm? This study contributes to the debate by examining the current ESG disclosure practices of the world's largest pension funds.

The findings from this study reveal that the disclosure practices of the world's largest pension funds are mixed depending on whether they are geographically located in North America or Europe. The findings reveal that North American funds exhibit poor outcomes in terms of RI disclosure to the general public. Conversely, European funds are found to be advocates of the public disclosure of ESG practices. We also find that the level of funds under management (FUM) is a strong explanatory variable to higher levels of RI disclosure to the general public.

The findings from this empirical study are relevant given the recent global financial crisis which has made decisions about the allocation of scarce resources and commitment towards RI disclosure more acute. The remainder of this study is organised as follows. The next section provides a brief survey of the literature. In the third section, we explore the concept and definition of RI. We then present the data collection process employed in this study. The methodology section outlines how RI is quantified and measured for each fund. We then analyse the results and provide concluding comments. 


\section{Literature Survey}

Whilst the ideals of ESG factors and RI are being driven by recent institutional initiatives (such as the UNPRI), the academic literature has examined the various definitions of these investment paradigms for some time under the different strands of research including SRI, ethical investing and the financial performance effects of corporate social performance. The works of Lee, Faff and Langfield-Smith (2009) and Statman and Glushkov (2009) inform us that there are three prevailing hypotheses (ie. advocates, critics and the neutral proponents) that dominate the ESG and RI debate in the financial economics literature.

Numerous empirical researchers advocate SRI, ethical and ESG approaches as they have demonstrated that a value creation proposition can be attained under this new investment philosophy. The two theoretical rationales that underpin the case for responsible investing is to, first seek new investment opportunities that deliver higher rates of returns to investors, and second, the long-term accumulation of RI based businesses and investment models remains a prudent method of risk management by avoiding investments that may be susceptible to risky outcomes.

The empirical literature has lent support to these hypotheses including Gompers et. al., (2003) who reveal evidence of a risk premium by owning stocks with high corporate social performance metrics and shorting a portfolio of stocks with low corporate social performance metrics. Others such as Derwall et. al., (2005) reveal the presence of an 'eco-efficiency' risk premium in SRI portfolios of US stocks from 1995-2003. More recently, Jiraporn and Gleason (2007) have discovered governance effects in stocks returns whereby an increase in corporate leverage results in a reduction in shareholder rights. The work of Konar and Cohen (2001) shows that poor environmental performance is negatively correlated to the intangible asset value of a firm. Other studies, such as Richard, Murthis and Ismail (2007) show that racial diversity within a firm is associated with positive financial performance.

The opponents of SRI, ethical investing and corporate social performance methods argue that the new investment paradigm is a cost and risk burden to investors and firms. From a Markowitz (1952) perspective, modern portfolio theory informs us that $\mathrm{RI}$ is a smaller subset of the investment universe that forms the market portfolio. A higher allocation or concentration towards RI will result in insufficient portfolio diversification for the investor resulting in unnecessary levels of portfolio risk. The second theoretical criticism comes from researchers such as Heinkel, Kraus and Zuechner (2001) who postulate that investors who avoid companies that are agnostic to ESG principles tend to keep the prices of these companies low thereby resulting in higher expected returns. The third theoretical criticism is that the additional cost burden to analyse and screen RI investments will give rise to higher management fees resulting in lower investment returns.

The empirical studies that critique the shift towards RI include Hassel, Nilsson and Nyquist (2005) who estimate that environmental investments lead to increased corporate costs which translate to a reduced market value of the firm. Galema, Plantinga and Scholtens (2008) find that SRI screening forms portfolios with lower book-to-market ratios which has significant effects on stock returns and reduces alpha. More recently, Hong and Kacperczyk (2009) show that "sin" stocks (i.e. 
gambling, alcohol and tobacco firms) earn a statistically and economically significant excess return of $2.5 \%$ per year in global stocks from 1985-2006 in comparison to the market return. From a managed fund expense perspective, Drew (2003) informs us that higher management fees translate into a drag in performance within the pension management industry. The empirical evidence from the critics provides a balancing offset or challenge to the RI advocates.

The third and final strand of literature suggests that the RI paradigm provides neutral outcomes towards investment and financial performance. For instance, Cortez, Silva and Areal (2009) find that European funds can screen investments based on social criteria without compromising financial performance. Bauer, Koedijk and Otten (2005) find no evidence of statistical differences in the risk-adjusted performance between ethical and conventional mutual funds in the US, UK and Germany in the 1990s. Others such as Statman (2006) estimate that the Domini 400 Social Index generated a higher return than the S\&P500 from 1990-2004, however, the outperformance is not statistically significant. Overall, it is clear that the evidence that support all three hypotheses in the literature leaves the question of the value of ESG approaches to investors as moot.

Whilst the literature has focussed on the financial and investment performance of corporate social responsibility, ethical, SRI and ESG behaviour, there is a paucity of research that measures whether this new paradigm is being taken seriously by the asset owners ${ }^{1}$ themselves. More specifically, is the emerging trend towards sustainable finance and investment being treated with importance by those who are the fiduciaries of the world's largest pools of long-term savings? ${ }^{2}$ Hawley and Williams (2000) and Monks (2001) acknowledge the global concentration of large pools of savings through trust institutions via the pension fund industry. Given this concentration, the shift towards a more sustainable world can only be actioned if ESG investment principles and practices are meaningful to the pension fund industry.

One way the paradigm shift toward ESG principles by pension funds can be demonstrated is by the public disclosure of these investment practices to their clients and to the general public. The Securities and Exchange Commission (2008) themselves have articulated the use of websites as an important tool for the disclosure of important corporate information. If RI is indeed a good, we would expect to observe these asset owners 'trumpeting' their strong support of, and commitment to, these new investment initiatives and practices via disclosure to the general public.

A second expectation of ours relates to leadership within the pension fund industry. Asset owners with the largest sums of funds under management hold more responsibility and influence as fiduciaries of these long-term savings in comparison to smaller asset owners. Large asset owners tend to yield greater media attention both

\footnotetext{
1 “Asset owners" is used herein to describe the organisations that have the ultimate fiduciary responsibility to investors. This differentiates between pension funds, which are asset owners, and asset management firms and other financial firms, which are usually agents of asset owners.

${ }^{2}$ For example, firms that are signatories to the United Nations Principles of Responsible Investing (PRI) are effectively permitted two years of 'non-compliance' before their genuine commitment to RI is evaluated. The U.N. has recently commenced the review process of addressing PRI signatories who are committed as signatories but do not demonstrate the PRI through visible corporate policies, activities and actions.
} 
within the finance industry, and the global economy more broadly. By virtue of the significant interests that these funds hold in all varieties of investments, especially listed corporations, they also tend to have a tangible impact on decision-making in the economy. For instance, if a senior investment professional at the California Public Employee Retirement System (known as CalPERS), one of the world's largest asset owners with $\$ 254.627$ billion under management, was to request a meeting the Chairman of the Board of a listed corporation, the authors would contend that such a meeting would very likely take place. The same probably can't be said for a smaller asset owner of, say, $\$ 1$ billion. By extension, there is an expectation that larger funds are, or at least should be, the motivational force to lead the pension fund industry towards these new ESG based principles and RI practices. Testing to see whether the size of funds under management is a proxy for public commitment to ESG principles is one of the subjects of this study. ${ }^{3}$

Given the positive 'corporate kudos' that is derived from ESG, asset owners that incorporate this new investment paradigm gain a competitive market edge via (i) first mover advantage and (ii) the development of innovative investment products. It is expected that the ESG activities of these asset owners be publicly disclosed for all to see. Furthermore, one would expect to observe the increasing importance of these ESG investment principles and practices as the proportion of funds under management increases.

A further matter of interest to policymakers is the potential for clear geographical variation in ESG approaches to investment. One popular notion to be tested in this study relates to the expectation that asset owners from Europe would show greater commitment to ESG principles than, say, North American asset owners controlling for size. Potential explanations include Europe's social economic models which tend to go beyond narrow economic definitions of utility, Europe's demonstrated commitment to social goods, and Europeans' willingness to subscribe to a range of treaties and agreements in particular relating to environmental issues (e.g. the Kyoto protocol). Given these factors, we expect see a greater degree of commitment to ESG principles from European asset owners.

This study examines the public disclosure of responsible investment activities of the world's largest asset owners, also often described as 'institutional investors'. Strictly speaking this category includes a range of fund types such as pension funds, buffer funds and sovereign wealth funds, which may hold assets for different purposes. The Pensions \& Investments/Watson Wyatt World 100: The Largest Pension Funds 2009 survey, which is used extensively in this study, leaves the reader expecting a list comprised of only pension funds. In reality, the list includes both buffer funds (e.g. Sweden's AP Fonden) and sovereign wealth funds (e.g. Australia's Future Fund), and hence the term 'pension fund' is used loosely throughout. As at 31 December 2008, Watson Wyatt (2009) reported that the assets of the eleven largest pension markets at an estimated US\$20,417 billion. To contextualise this result, the current value of pension fund assets constitutes $61 \%$ of the average GDP of the eleven markets at year-end 2008.

\footnotetext{
${ }^{3}$ The impact of fund size (as measured by funds under management) on the investment performance of mutual, pension and hedge funds has a long tradition. For an excellent review see Chen, Hong, Huang and Kubrik (2004). In a related strand of literature, Artiach, Lee, Nelson and Walker (2010) find evidence that corporate sustainability performance is positively related to firm size.
} 


\section{Responsible Investment}

Global investors are becoming increasingly aware of the potential impact of a myriad of issues such as climate change, human rights, and corporate governance practices on an investment proposition. In recent years, the new umbrella term, 'responsible investment' or RI has emerged in the finance industry to describe these effects on the conventional evaluation of an investment or financing proposition. ${ }^{4}$ Because large pension funds hold significant interests in companies and investment projects around the world, RI is seen by industry as a key element in advocating higher standards of practice amongst global investors and shifting capital to these areas in the future.

Whilst the RI terminology is entering mainstream, the challenge is to clearly define it given the ever-changing environment in the asset management industry. The introduction of new investment strategies including positive/negative screens of firms and sectors, new standards for corporate governance and various definitions of ethical and socially responsible investing makes it difficult to construct a formal definition of $\mathrm{RI}^{5}$

Despite the dynamic nature of RI, some international consensus has emerged in the form of the United Nations-backed Principles for Responsible Investment (PRI). The PRI is an internationally agreed framework to assist the global investment industry in incorporating ESG issues into the investment decision making process. There are six principles in the PRI that are voluntary and aspirational in nature but require higher investment and disclosure standards by organisations that are signatories to these commitments. $^{6}$ The emerging importance of ESG issues is reflected in the rapid growth of the PRI with 470 PRI signatories with assets under management of over US\$18 trillion as at July 2009 to up to 765 signatories in one year in July 2010. Given these statistics, this study examines the public disclosure of ESG practices as outlined in the PRI of the world's largest pension funds. We proceed to detail the data employed in this study.

\footnotetext{
${ }^{4}$ In the experience of the authors, the terms "responsible investment", "ethical investment", "socially responsible investment", "sustainable investment" and investment approaches incorporating "environmental, social and governance (ESG)" criteria tend to be used loosely and interchangeably in the finance industry. Whilst there are subtle differences between the five, we follow the convention and use these terms interchangeably.

${ }^{5}$ Ali (2007) explains the emergence of 'green' hedge funds who invest client funds in sustainablebased investments.

${ }^{6}$ The six United Nations Principles for Responsible Investment are available at www.unpri.org.
} 
Table 1: Summary of Pension Funds

Panel A presents the 97 funds in the study sorted by geographical region and we report the respective level of funds under management (FUM). The fourth column in this table reports the size of pension assets under management in each geographic sector as reported in the Watson Wyatt Worldwide (2009) Survey. The final column in this table reports the total FUM in each geographical region in this sample as a percentage of the total pension assets in each region. Panel B reports the funds sorted by quartiles and their respective FUM.

\begin{tabular}{llrrr}
\hline & Total FUM & Total Pension & Total FUM in Data \\
$\begin{array}{l}\text { Geographical } \\
\text { Region }\end{array}$ & $\begin{array}{l}\text { Number } \\
\text { of Funds }\end{array}$ & $\begin{array}{r}\text { In Data Sample } \\
\text { (US\$ millions) }\end{array}$ & $\begin{array}{r}\text { Assets } \\
\text { In Eample Region Percentage } \\
\text { (US\$ millions) }\end{array}$ & Assets Total Pension \\
\hline
\end{tabular}

Panel A: Funds Sorted By Continent

\begin{tabular}{llrrr}
\hline North America & 52 & $\$ 4,022,022$ & $\$ 13,165,000$ & $30.6 \%$ \\
Europe & 30 & $\$ 2,087,232$ & $\$ 3,747,000$ & $55.7 \%$ \\
Asia Pacific & 15 & $\$ 2,289,287$ & $\$ 3,449,000$ & $66.4 \%$ \\
\hline Total & 97 & $\$ 8,398,541$ & $\$ 20,361,000$ & $41.2 \%$ \\
\hline
\end{tabular}

Panel B: Funds Sorted by Quartiles

\begin{tabular}{llr}
\hline Q1 & 24 & $\$ 4,673,221$ \\
Q2 & 24 & $\$ 1,716,589$ \\
Q3 & 24 & $\$ 1,148,718$ \\
Q4 & 25 & $\$ 860,013$ \\
\hline
\end{tabular}

\section{DATA}

This study employs the P\&I/Watson Wyatt (2009) list of the largest 300 pension funds in the world ranked by funds under management in US dollar terms as at 31 December 2008 which was published in January 2009. From this independentlycompiled list, we examine the Top 100 largest pension funds as a proxy for global asset owners. ${ }^{7}$ The data from P\&I/Watson Wyatt (2009) provides the fund names, their world ranking based on funds under management (FUM), their country of domicile and their total FUM in US dollar terms.

We summarise the data by classifying each fund into their respective geographic region. From the sample of the Top 100, we exclude a single fund from the African region and two funds from the South American region to complete the final sample of 97 funds for the analysis in this study.

The summary of the 97 funds are reported in Table 1 and we reveal some interesting observations. Panel A of Table 1 shows that the 97 funds employed in this sample manage $41.2 \%$ (ie. $\$ 8.4$ trillion) of the $\$ 20.4$ trillion of total pension assets under management as reported in the Watson Wyatt Worldwide (2009) Survey. The significant level of assets under management as a proportion of total pension assets in each geographical region suggests that the 97 funds in this study not only represent the largest funds, but they represent a significant proportion of total global pension fund assets. Panel B of Table 1 shows that the 24 funds in the top quartile control $\$ 4.673$ trillion of funds which represents more than half of the $\$ 8.4$ trillion of funds

\footnotetext{
${ }^{7}$ The pension fund database and details of the survey are available from Watson Wyatt Investment consulting at www.watsonwyatt.com.
} 
under management in the sample and a staggering $23 \%$ of total world pension fund assets under management. As a result, it is important to acknowledge that the funds in this study are in fact the largest funds in each geographical region, however, they may not be representative of the overall global pension fund industry. Put simply, the public disclosure practices revealed in this study may in fact be representative of the behaviour of large pension funds rather than the global pension fund industry as a whole.

Panel A of Table 1 also shows that North American funds dominate the Top 97 with 52 funds managing US\$4.022 trillion. Panel A also reports that the second highest region with pension funds is Europe with 30 funds controlling US\$2.087 trillion of FUM. Europe and North America account for 82 funds managing US\$6.109 trillion or nearly 71 percent of FUM being managed in the sample. It is clear that both North America and European based funds dominate this sample of the largest pension funds in the world even though the Government Pension Investment Fund of Japan is ranked No.1 in the sample with US\$1.072 trillion of assets under management which represents one-eighth of total FUM in the data sample.

\section{METHODOLOGY}

The methodology of this study is designed to complement the United Nations Principles of Responsible Investment (PRI). Whilst there are some pension funds in this sample that are PRI signatories, there are many that do not voluntarily adopt the PRI. The design of this methodology is to measure the level of RI information that is disclosed to the general public. It is our contention that a pension fund which is a serious advocate of RI will do its utmost to communicate their RI philosophy and commitment to as many people as possible via their website. Some of these ESG standards are internally driven while others are determined by the pension fund in conjunction with collaborative input from external organisations/institutions. The objective of this methodology is to capture the public disclosure of each of these six PRI based outcomes.

We analyse the level of RI practice by these pension funds based on the information that the funds themselves disclose to the general public. For each pension fund, we enter their website to search and ascertain their level of public disclosure of RI activities. We allocated 60 minutes of internet time in their website between the dates of $1^{\text {st }}$ June and $15^{\text {th }}$ August 2009 and collected information that was readily available to the general public. We argue that a genuine advocate of RI would ensure that their ESG based information is easy to access on their public website. For each of the six PRI principles, we define tangible levels of public disclosure as important RI information that would be expected on the website of each pension fund. The six observable outcomes are detailed as follows:

Observable Outcome 1: Public reporting of any ESG related investment analysis and decision making processes.

Observable Outcome 2: Public reporting of ESG related ownership policy decisions. 
Observable Outcome 3: Public reporting of ESG standards demanded from the entities they invest in.

Observable Outcome 4: The entity is a signatory to the PRI?

Observable Outcome 5: If a PRI signatory, the pension fund enhances/promotes the PRI through collaboration via its information to the general public. For non-PRI signatories, the pension fund enhances/promotes RI dialogue via their engagement in other collaborative RI initiatives which are disclosed to the general public.

Observable Outcome 6: If a PRI signatory, the entity provides a PRI annual report to the general public. If a non-PRI signatory, the entity provides a RI annual report summarising their ESG activities to the general public.

\section{Logit and Multinomial Model Specifications}

To analyse the data in this study, we first employ a logit regression framework. This regression analysis is employed to examine: (i) the presence of a relationship between the level of RI public disclosure and the level of FUM of each asset owner; and (ii) whether there is any discernible geographic variation in responses to RI issues amongst asset owners. Logit analysis is a commonly used technique where a set of dichotomous (binary) outcomes (ie. 0 or 1 ) can be related to a set of explanatory variables. In the first case, we can test whether the public disclosure of RI practices by pension funds is dependent upon the level of FUM. To estimate this relationship, we can mathematically express it as follows. Let $N$ be the total number of observations (i.e. 100); $M$ is the number of explanatory variables; $x_{i j}$ is the value of the $j$ th variable for the $i$ th observation; $Y=Y_{1}, Y_{2}, \ldots, Y_{N}$ is the dependent variable which represents the RI criteria outcome: $Y_{i}=1$ for satisfying the RI criteria, $Y_{i}=0$ for not satisfying the RI criteria. The model in its general form can be expressed as:

$$
\operatorname{Pr}\left(Y_{i}=1\right)=F\left(x_{i 1}, x_{i 2}, \ldots, x_{i M}, b_{1}, b_{2}, \ldots\right),
$$

That is, the probability that $Y_{i}=1$ is a function of that observation's $x_{i j}$ values and of $b_{1}, b_{2}$, etc. which are parameters estimated from the sample data. The form of the probability function $F$ is assumed although alternative specifications of $F$ may be tested in order to select the most appropriate form of $F$.

The assumed functional form in the logit model is the logistic function which can be written as:

$$
\operatorname{Pr}\left(Y_{i}=1\right)=P_{i}=\frac{1}{1+e^{-W_{i}}}, \quad i=1, \ldots, N
$$

where $w_{i}=b_{0}+\sum_{j=1}^{M} b_{j} x_{i j}$ is a linear combination of the independent variables and a set of coefficients $B=\left(b_{0}, b_{1}, \ldots b_{M}\right)$ which are to be estimated. In this model, we assume that there is a simple linear combination of $W$ independent variables that is positively related to the probability of public disclosure of RI. That is, the higher value of $W_{i}$, 
the higher the probability of public disclosure of RI activities conditional on the pension fund's value of $x$. The coefficient vector $B$ of this linear combination is not known a priori, but must be inferred from the known values of $x \mathrm{~s}$ and Ys. In this first model, we employ FUM as the independent variable to examine whether RI public disclosure is dependent upon the size of assets under management. To obtain the parameter estimates of the model, maximum likelihood estimation (MLE) is used.

A similar specification is applied to the second model, which seeks to identify geographical variation in asset owner responses to RI issues. In model two, the dependent variable remains the RI criteria outcome as in model one. There are two independent variables: (i) a binary variable where $X_{i}=1$ where the asset owner is European, and $X_{i}=0$ where the asset owner is non-European; and (ii) the FUM variable from model one in order to control for size. We also conduct an auxiliary regression of this second model where the binary independent variable takes the value of unity where the asset owner is North American and zero where the asset owner is not North American.

In this study, we also employ a multinomial regression to examine the total score of each fund. For the multinomial logit regression specification, $Y=Y_{1}, Y_{2}, \ldots, Y_{N}$ is the dependent variable which represents the RI criteria outcome for values ranging from 0 to 6 and can be expressed in its general form as:

$$
\operatorname{Pr}\left(Y_{i}=0,1,2,3,4,5,6\right)=F\left(x_{i 1}, x_{i 2}, \ldots, x_{i M}, b_{1}, b_{2}, \ldots\right)
$$

Table 2: Summary of Public Disclosure Results

This table summarises the public disclosure findings of the 97 funds. Panel A reports the number of funds that satisfy each disclosure criterion. Panel B classifies each of these funds based on geographical continent. Panel C classifies these funds based on their quartile measured by FUM. Panel D measures the total FUM being managed by funds that meet or fail to disclose each criterion.

\begin{tabular}{cccccc} 
Criteria & Criteria & Criteria & Criteria & Criteria & Criteria \\
No.1 & No. 2 & No.3 & No.4 & No.5 & No.6 \\
\hline
\end{tabular}

Panel A: Number of Funds That Meet Criteria

\begin{tabular}{lllllll}
\hline Total & 45 & 33 & 26 & 24 & 30 & 13
\end{tabular}

Panel B: Sorted by Continent

\begin{tabular}{lcccccc}
\hline North America & 20 & 15 & 11 & 8 & 14 & 3 \\
Europe & 21 & 17 & 14 & 15 & 15 & 9 \\
Asia Pacific & 4 & 1 & 1 & 1 & 1 & 1
\end{tabular}

Panel C: Sorted by Quartile

\begin{tabular}{lcccccc}
\hline Q1 & 16 & 13 & 10 & 9 & 11 & 5 \\
Q2 & 10 & 9 & 7 & 3 & 5 & 2 \\
Q3 & 11 & 5 & 3 & 5 & 8 & 0 \\
Q4 & 8 & 6 & 6 & 7 & 6 & 6
\end{tabular}

Panel D: Sorted by Funds under Management (US\$ millions)

\begin{tabular}{lllllll}
\hline Criteria Met & $4,969,717$ & $3,298,682$ & $3,620,874$ & $3,340,944$ & $3,861,100$ & $2,364,980$ \\
Criteria Not Met & $3,428,824$ & $5,099,859$ & $4,777,667$ & $5,057,597$ & $4,537,441$ & $6,033,561$ \\
\hline
\end{tabular}




\section{Results}

The survey results of each fund is collected and summarised in Table 2. Outcome 1 reports the most elementary public disclosure of ESG practices of all funds. Panel A of Table 2 reports that $46 \%$ of funds (ie. 45 out of 97) were found to disclose this basic level of RI information on their website. Panel B of Table 2 reports that 21 of the 30 European funds (i.e. 70\%) meet this criterion while only 20 of the 52 North American funds (i.e. 38\%) disclose elementary discussion of ESG investment factors to the general public. These observations suggest that European pension funds are more committed to providing the public disclosure of RI information than their North American peers.

Outcome 2 measures the public reporting of active ownership decisions and Panel A of Table 2 reports that $34 \%$ of funds (ie. 33 out of 97) in the sample met this disclosure criterion. Panel B of Table 2 shows that 17 out of 30 European funds (or 57\%) provided public reporting of active ownership whilst only 15 out of 52 North American funds (or 29\%) show similar disclosure. Once again, these findings indicate that the public disclosure of active ownership is low, however, European funds tend to provide a higher level of public information than their North American colleagues. Panel C of Table 2 reports that 13 of 25 funds (or 52\%) in the top quartile (based on FUM) demonstrate public reporting of active ownership while only 6 of 25 funds (or 24\%) of the bottom quartile disclose the same information. This outcome lends support to the notion that larger pension funds generally display a higher degree of public RI disclosure, however, this will be addressed in subsequent sections of this study. Overall, we can conclude that the North American region provides limited public disclosure of active ownership decisions in comparison to Europe.

Outcome 3 quantifies the public reporting of ESG standards demanded from the entities they invest in and Panel A of Table 2 reveals that 26 of the 97 funds (or just over one-quarter surveyed) disclose this information to the general public. Panel B of Table 2 shows there are 14 European funds from a total of 30 (i.e. 47\%) that meet this criterion, while 11 out of 52 North American funds (i.e. 21\%) provide an equivalent level of public disclosure. Again, this criterion reveals that North American pension funds fall short in this form of public disclosure in comparison to their European counterparts. Panel $\mathrm{C}$ of Table 2 reports that 10 funds in the top quartile (i.e. 41.6\%) meet this criterion of public disclosure. Conversely, only 6 funds in the bottom quartile satisfy this criterion. Panel $\mathrm{C}$ of Table 2 appears to suggest that the largest funds classified by FUM seem to be provide RI disclosure leadership, and greater transparency amongst those surveyed.

Outcome 4 measures whether the entity is a PRI signatory. Panels A and B of Table 2 show that 24 funds meet this criterion of which 15 funds are based in Europe. These 24 PRI signatories control approximately $40 \%$ of total funds under management in this sample. An interesting observation from Panel $\mathrm{C}$ of Table 2 is that the 24 PRI signatories are concentrated in the top quartile ( 9 funds) with fewer funds in the remaining quartile categories. 
Outcome 5 captures a pension fund's public disclosure of the promotion of RI dialogue and initiatives with other entities. Panel A of Table 2 reveals that $31 \%$ of the 97 funds met this disclosure criterion. Fifteen out of 30 European funds (i.e. 50\%) disclosed information that met this criterion in comparison with only 14 of the 52 North American funds (i.e. 27\%). An interesting observation from Panel C of Table 2 is that 11 of the 24 funds (i.e. 46\%) in the top quartile of FUM satisfied this criterion. Many pension funds in the Top 97 met this criterion through their participation and membership of other ESG-related initiatives including those listed in the Introduction section of this study. The purpose of these organisations is to enhance awareness and develop new ESG-type standards through collaborative dialogue with other investors and market participants. Pension funds that were not signatories of the PRI or one or more of these other organisations generally met this criterion by enhancing and promoting RI through their own corporate activities.

Outcome 6 measures whether the pension fund discloses a PRI or RI annual report to the general public. Panel A of Table 2 reports that only 13 of the 97 funds in the sample satisfied this criterion. Panel B of Table 2 shows that 9 out of 30 European funds (or 30\%) and only 3 from 52 North American funds (or 6\%) provided a RI annual report to the general public. Interestingly, Panel C of Table 2 reveals that the funds who produce RI annual reports tend to be categorised in the top and bottom quartile in terms of FUM. We also observe that 10 of the 13 funds (i.e. $77 \%$ ) that publish a RI annual report are PRI signatories. The findings from Outcome 6 suggest that pension funds do not feel that it is necessary to disseminate RI activities through a $\mathrm{RI}$ annual report. Another interesting finding is that the pension funds who provide RI annual reports to the general public are overwhelmingly PRI signatories, however, it is clear that the disclosure of this type of reporting is not yet an industry standard in the global pension fund industry.

\section{Table 3: Equality Tests}

This table presents the test statistics of various equality tests of medians and variances. Panels A and B report the hypothesis tests from the total score out of six (from the six PRI based outcomes) of each fund categorised in their respective continental/geographical locations of North America, Europe or the Asia Pacific. Panels C and D report the hypothesis tests based on funds in their respective quartiles ranked by funds under management (FUM). Panels A and C present the nonparametric Mann-Whitney equality of median tests. Panels B and D report the nonparametric Siegel-Tukey difference in scale (variance) test. $*$ and $* *$ denote statistical significance at the $5 \%$ and $1 \%$ levels, respectively.

Panel A: Grouped by Geographical Location - Equality of Median Tests

\begin{tabular}{rcc}
\multicolumn{1}{c}{} & North America & Europe \\
\cline { 2 - 3 } Europe & $3.081^{* *}$ & $\mathrm{n} / \mathrm{a}$ \\
Asia Pacific & 1.158 & $3.070^{* *}$
\end{tabular}

Panel B: Grouped by Geographical Location - Equality of Variance Tests

\begin{tabular}{rcc}
\multirow{2}{*}{} & North America & Europe \\
\cline { 2 - 3 } Europe & 1.268 & $\mathrm{n} / \mathrm{a}$ \\
Asia Pacific & 0.939 & 0.320
\end{tabular}


Panel C: Grouped by FUM Quartiles: Equality of Median Tests

\begin{tabular}{lcccc} 
& Q1 & Q2 & Q3 & Q4 \\
\cline { 2 - 5 } Q1 & ---- & & & \\
Q2 & 0.175 & ---- & & \\
Q3 & 0.433 & 0.691 & ---- & \\
Q4 & 1.588 & 1.856 & 1.041 & ----
\end{tabular}

Panel D: Grouped by FUM Quartiles: Equality of Variance Test

\begin{tabular}{lcccc}
\hline & & & & \\
\cline { 2 - 5 } Q1 & Q1 & Q2 & Q3 & Q4 \\
Q2 & 0.396 & - & & \\
Q3 & 0.489 & 1.053 & ---- & \\
Q4 & -0.003 & 0.589 & 0.5590 & --- \\
\hline
\end{tabular}

\section{Equality Tests}

The findings in Table 2 suggests the strong influence of the North American and European funds in this sample and the strong effect that seems to be present on the top quartile of funds with the largest FUM. To examine whether these effects are statistically significant, Table 3 reports the nonparametric tests for equality of median and variance. Panel A of Table 3 sorts the funds based on their continental location and we estimate the nonparametric Mann-Whitney equality of median test. Panel A reveals that the difference in expected scores of European funds are statistically significant in comparison to their counterparts in North American and Asia Pacific. Put simply, European funds tend to exhibit higher and statistically significant scores for public disclosure of RI practices in comparison to North American and Asia Pacific funds. It is clear that European funds tend to value the public disclosure of ESG factors in the investment process more than their US counterparts. Panel B of Table 3 reports the nonparametric Siegel-Tukey test which shows insignificant differences in the dispersion of scores between North American, European and Asia Pacific funds.

In a second analysis, we test the strength of the overall RI scores based on FUM, we estimate the same equality tests on the funds classified in their respective FUM quartiles. Panel C and D of Table 3 show no statistical difference in median or variance in funds when classified in their respective FUM quartiles. Thus, we cannot draw any conclusions that FUM is or is not a variable that can be associated with the public disclosure of RI. 
Table 4: Multinomial Regression

This table presents the multinomial regression employing a quasi maximum likelihood (QML) estimation with the quadratic hill climbing optimization algorithm. The dependent variable in the estimation is the total scores from zero to six for the 97 funds. The three independent variables in the estimation are the log of funds under management (FUM), the binary criteria (ie. 1 or 0 ) for European funds and the binary criteria (ie. 1 or 0 ) for North American funds. Standard errors (SE) are based on Huber / White robust covariances. $*$ and $* *$ denote statistical significance at the $5 \%$ and $1 \%$ levels, respectively.

\begin{tabular}{lccccc}
\hline $\begin{array}{l}\text { Regression } \\
\text { Coefficients }\end{array}$ & Coefficient Estimate / SE / p-value & $\begin{array}{c}\text { Log } \\
\text { Likelihood }\end{array}$ & $\begin{array}{c}\text { LR } \\
\text { Statistic }\end{array}$ & $\begin{array}{c}\text { LR } \\
\text { p-value }\end{array}$ & $\begin{array}{c}\text { Adj. } \\
\mathrm{R}^{2}\end{array}$ \\
\hline Intercept & $-5.920 / 1.333 / 0.000$ & -250.949 & 129.922 & 0.000 & 0.263 \\
Log(FUM) & $0.504 / 0.118 / 0.000^{* *}$ & & & \\
European Fund & $1.433 / 0.368 / 0.000^{* *}$ & & & & \\
N.American Fund & $0.669 / 0.396 / 0.092$ & & & \\
\hline
\end{tabular}

\section{Multinomial Estimation}

We estimate a multinomial logistic regression that simultaneously examines whether the total scores of each fund can be explained by the size of FUM and the continental locations of Europe and North America. The multinomial regression results in Table 4 indicate that both FUM size and the European location are statistically significant with large and positive coefficient estimates. Table 4 also reveals that the parameter estimate for the location of North American funds is positive and large, however, it is statistically significant at the $10 \%$ level only.

Overall, the findings in Table 4 contribute to the weight of evidence that a European fund domicile seems to be a strong and reliable explanatory variable for overall scores of RI public disclosure. The multinomial regression also provides evidence that suggests that FUM is a significant explanatory variable, even after controlling for location. This finding leads to the obvious question about why larger pension funds might demonstrate a greater commitment to ESG issues. Potential explanations may include: greater access to resources including specialised ESG expertise, more established and capable investment governance arrangements, and/or a predisposition, by virtue of size, to taking positions of leadership amongst asset owners. Given the inconsistent findings in comparison to the equality tests, we pursue another regression which examines the results of the individual scores of each fund. 
Table 5: Logit Regressions

This table presents the logit regression results estimated in this study. Panel A reports the logit regressions with the binary criteria (ie. 0 or 1 ) of Criterion 1 to 6 as the dependent variable and the log of the amount of funds under management as the independent variable. Panel B reports the logit regressions with the binary criteria (ie. 0 or 1 ) of Criterion 1 to 6 as the dependent variable and the criteria of 1 for European funds and 0 for non-European funds as the independent variable. Panel $\mathrm{C}$ reports the logit regressions with the binary criteria (ie. 0 or 1 ) of Criterion 1 to 6 as the dependent variable and the criteria of 1 for North American funds and 0 for non North American funds as the independent variable. Standard errors are based on Huber / White robust covariances. * and ** denote statistical significance at the $5 \%$ and $1 \%$ levels, respectively.

\begin{tabular}{|c|c|c|c|c|c|c|}
\hline Criteria & $\begin{array}{l}\text { Regression } \\
\text { Coefficients }\end{array}$ & Coefficient Estimate / SE / p-value & $\begin{array}{c}\text { Log } \\
\text { Likelihood } \\
\end{array}$ & $\begin{array}{c}\text { LR } \\
\text { Statistic }\end{array}$ & $\begin{array}{c}\text { LR } \\
\text { p-value }\end{array}$ & $\begin{array}{c}\text { McFadden } \\
\mathrm{R}^{2}\end{array}$ \\
\hline \multicolumn{7}{|l|}{ Panel A: } \\
\hline 1 & $\begin{array}{l}\text { Intercept } \\
\text { Log(FUM) }\end{array}$ & $\begin{array}{l}-8.534 \text { / } 3.686 \text { / } 0.021 \\
0.756 \text { / } 0.332 \text { / 0.023* }\end{array}$ & -66.446 & 5.098 & $0.024 *$ & 0.037 \\
\hline 2 & $\begin{array}{l}\text { Intercept } \\
\text { Log(FUM) }\end{array}$ & $\begin{array}{c}-9.025 \text { / - } 1.967 \text { / } 0.049 \\
0.753 \text { / } 1.819 \text { / } 0.069\end{array}$ & -61.595 & 5.017 & $0.025^{*}$ & 0.039 \\
\hline 3 & $\begin{array}{l}\text { Intercept } \\
\text { Log(FUM) }\end{array}$ & $\begin{array}{c}-10.772 \text { / } 3.929 \text { / } 0.006 \\
0.877 \text { / } 0.348 \text { / } 0.012^{*}\end{array}$ & -55.189 & 6.273 & $0.012 *$ & 0.054 \\
\hline 4 & $\begin{array}{l}\text { Intercept } \\
\text { Log(FUM) }\end{array}$ & $\begin{array}{c}-7.612 \text { / } 4.139 \text { / } 0.066 \\
0.585 \text { / } 0.367 \text { / } 0.111\end{array}$ & -54.834 & 2.799 & 0.094 & 0.025 \\
\hline 5 & $\begin{array}{l}\text { Intercept } \\
\text { Log(FUM) }\end{array}$ & $\begin{array}{c}-8.638 /-2.358 / 0.018 \\
0.705 / 2.163 / 0.031^{*}\end{array}$ & -59.738 & 4.345 & $0.037 *$ & 0.035 \\
\hline 6 & $\begin{array}{l}\text { Intercept } \\
\text { Log(FUM) }\end{array}$ & $\begin{array}{c}-9.808 \text { / } 5.513 \text { / } 0.076 \\
0.707 / 0.485 \text { / } 0.145\end{array}$ & -37.639 & 2.829 & 0.093 & 0.036 \\
\hline \multicolumn{7}{|l|}{ Panel B: } \\
\hline 1 & $\begin{array}{l}\text { Intercept } \\
\text { European Fund }\end{array}$ & $\begin{array}{c}-0.588 \text { / } 0.249 \text { / } 0.019 \\
1.435 / 0.470 / 0.002^{* *}\end{array}$ & -63.949 & 10.091 & $0.001 * *$ & 0.073 \\
\hline 2 & $\begin{array}{l}\text { Intercept } \\
\text { European Fund }\end{array}$ & $\begin{array}{l}-1.137 / 0.279 / 0.000 \\
1.405 / 0.461 / 0.002^{* *}\end{array}$ & -59.332 & 9.544 & $0.002 * *$ & 0.074 \\
\hline 3 & $\begin{array}{l}\text { Intercept } \\
\text { European Fund }\end{array}$ & $\begin{array}{c}-1.478 \text { / } 0.307 / 0.000 \\
1.345 / 0.478 / 0.005^{* *}\end{array}$ & -54.324 & 8.004 & $0.005 * *$ & 0.069 \\
\hline 4 & $\begin{array}{l}\text { Intercept } \\
\text { European Fund }\end{array}$ & $\begin{array}{c}-1.792 / 0.342 / 0.000 \\
1.793 / 0.500 / 0.000^{* *}\end{array}$ & -49.503 & 13.462 & $0.000 * *$ & 0.120 \\
\hline 5 & $\begin{array}{l}\text { Intercept } \\
\text { European Fund }\end{array}$ & $\begin{array}{c}-1.216 / 0.285 / 0.000 \\
1.216 / 0.463 / 0.009 * *\end{array}$ & -58.423 & 6.975 & $0.008 * *$ & 0.056 \\
\hline 6 & $\begin{array}{l}\text { Intercept } \\
\text { European Fund }\end{array}$ & $\begin{array}{c}-2.803 / 0.515 / 0.000 \\
1.956 / 0.651 / 0.003^{* *}\end{array}$ & -33.658 & 9.961 & $0.002 * *$ & 0.129 \\
\hline \multicolumn{7}{|l|}{ Panel C: } \\
\hline 1 & $\begin{array}{l}\text { Intercept } \\
\text { N.American Fund }\end{array}$ & $\begin{array}{c}0.167 / 0.290 / 0.564 \\
-0.637 / 0.406 / 0.117\end{array}$ & -67.751 & 2.487 & 0.115 & 0.018 \\
\hline 2 & $\begin{array}{l}\text { Intercept } \\
\text { N.American Fund }\end{array}$ & $\begin{array}{l}-0.423 / 0.295 / 0.152 \\
-0.480 / 0.425 / 0.259\end{array}$ & -63.462 & 1.284 & 0.257 & 0.010 \\
\hline 3 & $\begin{array}{l}\text { Intercept } \\
\text { N.American Fund }\end{array}$ & $\begin{array}{l}-0.693 / 0.306 / 0.024 \\
-0.623 / 0.457 / 0.173\end{array}$ & -57.384 & 1.884 & 0.170 & 0.016 \\
\hline 4 & $\begin{array}{l}\text { Intercept } \\
\text { N.American Fund }\end{array}$ & $\begin{array}{c}-0.601 / 0.302 / 0.047 \\
-1.104 / 0.489 / 0.024 *\end{array}$ & -53.520 & 5.419 & $0.020 *$ & 0.048 \\
\hline 5 & $\begin{array}{l}\text { Intercept } \\
\text { N.American Fund }\end{array}$ & $\begin{array}{l}-0.601 / 0.302 / 0.047 \\
-0.398 / 0.435 / 0.360\end{array}$ & -61.489 & 0.842 & $0.020 *$ & 0.048 \\
\hline 6 & $\begin{array}{l}\text { Intercept } \\
\text { N.American Fund }\end{array}$ & $\begin{array}{c}-1.335 \text { / } 0.355 / 0.000 \\
-1.458 \text { / } 0.693 \text { / 0.035* }\end{array}$ & -36.033 & 5.211 & $0.022 *$ & 0.067 \\
\hline
\end{tabular}




\section{Logit Estimation}

As a final analysis, we examine the individual results of each fund and examine whether size of FUM or continental location are explanatory variables to these scores. Table 5 reports the logit regression results by employing the six criteria results as the dependent variable with various independent variables. Panel A of Table 5 reveals that the size of FUM is a statistically significant explanatory variable of public disclosure for Criteria 1, 3 and 5 but not for 2, 4 and 6. It is not immediately clear why this is the case, however, this inconsistency may explain why FUM size was found to be an insignificant variable in the equality tests yet it is a significant explanatory variable in explaining the overall scores in the multinomial regression results.

Panel B of Table 5 suggests that European funds are a statistically significant variable at explaining an affirmative criterion score in this sample. This result lends further support to suggest that this is the most important explanatory variable of public RI disclosure in this sample. Conversely, Panel C of Table 5 reveals that North American funds are an insignificant variable at explaining the public disclosure of RI information with the exception of Criteria 4 and 6. Overall, the conclusions to be drawn from Table 5 are that the size of FUM and European funds are generally strong explanatory variables of RI disclosure to the general public.

Figure 1: Fragmentation of RI Practices

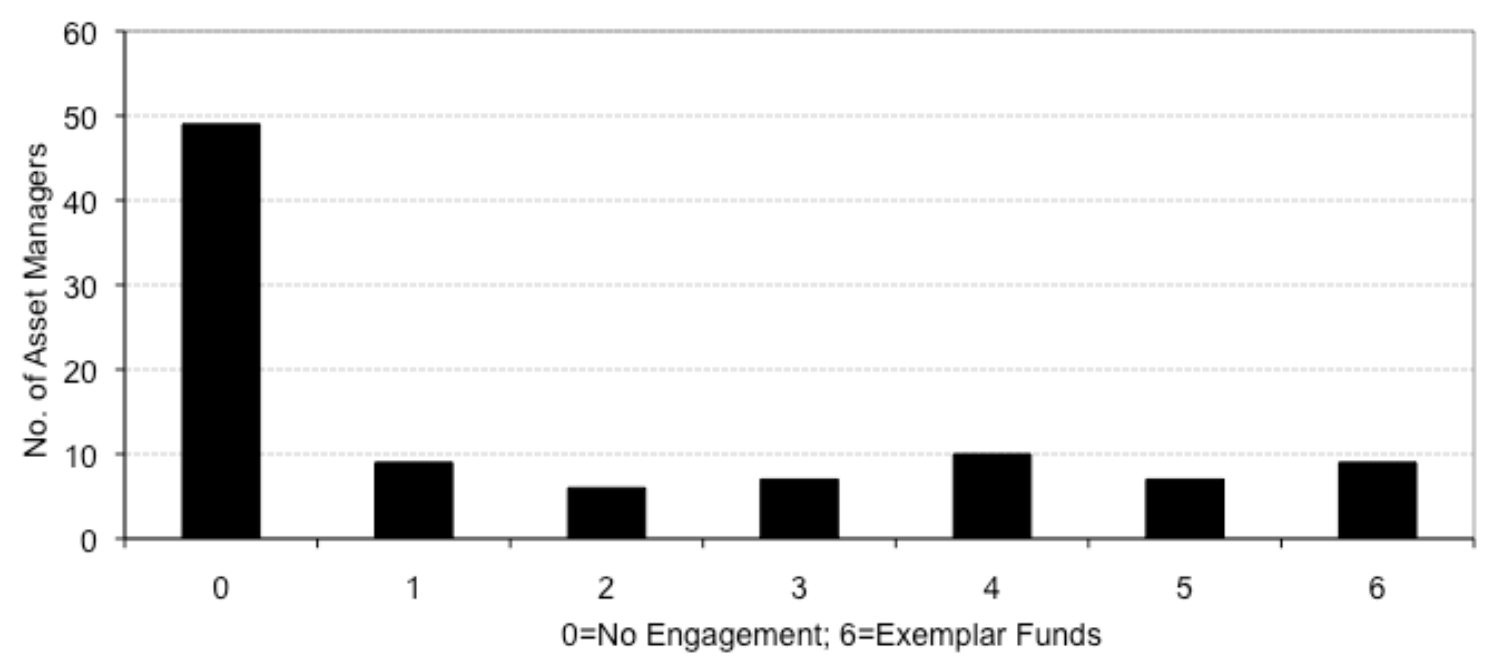




\section{Findings}

The findings from this study on the public disclosure of RI practices reveal a number of themes that relate to issues of transparency, fragmentation, geography and fund size. First, the activities observed from the websites of this sample suggests that, while pockets of excellence exist in terms of public disclosure, the ongoing dichotomy between a relatively homogenous, aspirational set of RI goals and a heterogeneous set of operational responses by these fiduciaries of long-term savings is clear. This raises the spectre of information asymmetry from Akerlof (1970), Spence (1973) and Stiglitz (2000) whereby the transactions between pension funds and their members may be stifled if these contracting parties do not exhibit homogenous expectations in terms of RI. A commitment by the asset owners to improve the transparency of their fund's RI practices through public disclosure can minimise the potential for market failure.

Second, this study reveals that the observed practices of the largest pension funds confirm a heterogeneous set of responses to RI issues. Within the sample of 97 pension funds, the spectrum of outcomes is dramatic especially between the European funds and others. Whilst dominated by asset owners that appear to make no formal mention of RI considerations on their websites, around one in four of these pension funds (27\%) have a rating of four or higher on the survey scale (see Figure 1). This group is skewed toward larger funds representing $43 \%$ or $\$ 3.6$ trillion of total assets.

This raises some immediate questions for future research. What are the barriers (real or perceived) to fiduciaries of the world's largest pension funds in more fully disclosing their RI practices to the general public? Whilst it is encouraging that, by total assets, funds engaged in the public disclosure of RI practices (defined as pension funds with a rating of four or above on the scale) account for a slightly greater proportion of capital than those not engaged (43\% or $\$ 3.6$ trillion versus $38 \%$ or $\$ 3.2$ trillion), a substantial pool of retirement savings are, according to website sources, yet to engage in the RI debate publicly. The observations drawn from this research suggest the emergence of two main cohorts within the largest pension funds, that is, around four out of ten engaged in the RI debate; with four out of ten funds having no public engagement; and the remaining two funds out of ten engaging only partially. A limitation of this study is the dominant proportion of North American pension funds who seem less engaged in the public disclosure of RI than pension funds located in other geographical areas.

The geographic region of Europe (incorporating funds mainly from Denmark, Netherlands, Norway, and Sweden) have demonstrated leadership in the public disclosure of RI practices in this sample. It has been noted that the funds with the highest RI disclosure seem to belong to an area which could loosely be described as 'northern Europe.' [Had it not been for the presence of a Dutch fund in the group, 'Scandinavia' would have been a better descriptor for this set of funds.] This real commitment to RI disclosure amongst certain northern European countries could be explained in a number of ways: northern Europeans' strong social democratic systems of government, a common set of norms, or a social consensus supporting good causes. In any case, why northern European funds figure so prominently amongst this study's exemplary funds merits further investigation. In terms of FUM size, the evidence from this study remains mixed. Whilst the multinomial estimation demonstrates that a 
fund's assets under management may explain the overall scores in public RI disclosure, contradictory results were found with equality tests. When individual scores were regressed against the size of FUM, the logit regression estimates provided both significant and insignificant findings. A limitation of this study is the fact that the Top 97 funds are examined and these results may reflect this type of 'large pension firm bias' in the results rather than reflecting the findings of the overall pension fund industry. It is clear that the issue of FUM size in the RI debate remains an area for future research.

\section{Concluding Comments}

While not the focus of this study, a point that cannot be emphasised enough in fiduciary discussions regarding RI disclosure is the outcomes for pension fund investors (ie. the beneficiaries) and the impact that RI policies may have had on their final accumulated balance. ${ }^{8}$ Members' interests are inherently long term, and the current dislocation between those funds 'engaged' and 'not engaged' in the RI debate requires immediate consideration. It appears timely that the investment merits of the RI debate are fully tested to allow pension funds to fulfil their economic obligation of efficiently and effectively transforming retirement savings into retirement income. The first step is the elementary disclosure of their RI activities. Only through the completion of this task can fiduciaries ultimately fulfil their obligation to their beneficiaries.

Perhaps due to the fact that the goals of RI and its disclosure are aspiration driven, the debate to date has tended to generate much heat, but little light. Current practices by the largest pension funds suggest that a dichotomy of views exists in different geographical locations around the world. Perhaps one way to progress the debate is not to contextualise the findings of this survey as pension funds being 'right' or 'wrong', but a difference of philosophical views based on the belief in the investment merits of RI practices and disclosure. However, the global shift towards the RI paradigm is becoming so strong, that equally compelling evidence needs to be produced by pension funds not engaged in RI practices to inform their policy stance.

\footnotetext{
${ }^{8}$ This idea is explored in Drew (2009) particularly relating to the perils of short-termism in the design of pension fund mandates.
} 


\section{References}

Akerlof, George A. (1970). The Market for 'Lemons': Quality Uncertainty and the Market Mechanism. Quarterly Journal of Economics 84 (3), 488-500.

Ali, Paul., (2007). Investing in the Environment: Some Thoughts on the New Breed of Green Hedge Funds. Journal of Derivatives and Hedge Funds 12 (4), 351357.

Artiach, T., Lee, D., Nelson, D. and Walker, J., (2010). The determinants of corporate sustainability performance. Accounting and Finance 50 (1), 31-51.

Bauer, R., Koedijk, K. and Otten, R., (2005). International Evidence On Ethical Mutual Fund Performance and Investment Style. Journal of Banking and Finance 29 (7), 1751-1767.

Chen, J., H. Hong, M. Huang, and J. Kubrik, 2004, Does Fund Size Erode Mutual Fund Performance? The Role of Liquidity and Organization, American Economic Review 94, 1276-1302.

Cortez, M., Silva, F. and Areal, N., (2009). The Performance of European Socially Responsible Funds. Journal of Business Ethics 87, 573-588.

Derwall, J., Guenster, N., Bauer, R. and Koedijk, K., (2005). The Eco-Efficiency Premium Puzzle. Financial Analysts Journal 61 (2), 51-63.

Drew, Michael (2003). Superannuation funds: fees and performance, JASSA 3, Spring, 31-36.

Drew, Michael (2009). The Puzzle of Financial Reporting and Corporate ShortTermism: A Universal Ownership Perspective', Australian Accounting Review 19(4), 295-302.

Galema, R., Plantinga, A. and Scholtens, B, (2008). The stocks at stake: Return and Risk of Socially Responsible Investment. Quarterly Journal of Economics 32, 2646-2654.

Gompers, P., Ishii, J. and Metrick, A, (2003). Corporate Governance and Equity Prices. Quarterly Journal of Economics 118 (1), 107-155.

Hassel, L., Nilsson, H. and Nyqvist, S., (2005). The Value Relevance of Environmental Performance. European Accounting Review 14(1), 41-61.

Hawley, J. P. and A. T. Williams, 2000, The Rise of Fiduciary Capitalism: how institutional investors can make corporate America more democratic, PA: University of Pennsylvania Press: Philadelphia. 
Hong, H. and Kacperczyk, M., (2009). The Price of Sin: The Effect of Social Norms on Markets. Journal of Financial Economics 93 (1), 15-36.

Jiraporn, P. and Gleason, K., (2007). Capital Structure, Shareholder Rights and Corporate Governance. Journal of Financial Research 30 (1), 21-33.

Koner, S. and Cohen, M., (2001). Does the Market Value Environmental Performances. Review of Economics and Statistics 83(2), 281-289.

Lee, D., Faff, R. and Langfield-Smith, K., (2009). Revisiting the Vexing Question: Does superior Corporate Social Performance Lead to Improved Financial Performance?. Australian Journal of Management 34(1), 21-49.

Markowitz, H., (1952). Portfolio Selection. Journal of Finance 7(1), 77-91.

Monks, R, 2001, The New Global Investors: How shareowners can unlock sustainable prosperity worldwide, Capstone Publishing Limited: Oxford.

Richard, O., Murthi, B. and Ismail, K., (2007). The Impact of Racial Diversity on Intermediate and Long-Term Performance: The Moderating Role of Environmental Context. Strategic Management Journal 28, 1213-1233.

Securities and Exchange Commission. (2008). Commission Guidance on the Use of Company Web Sites, 17 CFR Parts 241 and 271 [Release Nos. 34-58288, IC58351; File No. S7-23-08]. Available at: <http://www.sec.gov/rules/interp/2008/34-58288.pdf>

Spence, Michael (1973). Job Market Signaling. Quarterly Journal of Economics 87 (3), 355-374.

Statman, M., (2006). Socially Responsible Indexes. Journal of Portfolio Management 32 (3), Spring, 100-109.

Statman, M., and Glushkov, D., (2009). The Wages of Social Responsibility. Financial Analysts Journal 65 (4), 33-46.

Stiglitz, Joseph E. (2000). The Contributions of the Economics of Information to Twentieth Century Economics, Quarterly Journal of Economics, 115(4), 14411478.

Watson Wyatt Worldwide, 2009, Global Pensions Survey, January. 


\section{About the authors}

Robert J. Bianchi is a Senior Lecturer at the Department of Accounting, Finance and Economics at the Griffith Business School, Griffith University, Queensland, Australia. Robert Bianchi is the corresponding author and can be contacted at: r.bianchi@griffith.edu.au

Michael E. Drew is a Professor at the Department of Accounting, Finance and Economics, Griffith Business School, Griffith University, Queensland, Australia.

Adam N. Walk is a $\mathrm{PhD}$ candidate at the Department of Accounting, Finance and Economics, Griffith Business School, Griffith University, Queensland, Australia. 